University of Nebraska - Lincoln

DigitalCommons@University of Nebraska - Lincoln

USDA National Wildlife Research Center - Staff Publications
U.S. Department of Agriculture: Animal and Plant Health Inspection Service

2010

\title{
Foot-and-Mouth Disease in Feral Swine: Susceptibility and Transmission
}

\author{
F. Mohamed \\ USDA, APHIS
}

S. Swafford

USDA, APHIS

H. Petrowski

USDA, APHIS

A. Bracht

USDA, APHIS

B. S. Schmit

USDA/APHIS/WS National Wildlife Research Center, Brandon.S.Schmit@aphis.usda.gov

See next page for additional authors

Follow this and additional works at: https://digitalcommons.unl.edu/icwdm_usdanwrc

Part of the Environmental Sciences Commons

Mohamed, F.; Swafford, S.; Petrowski, H.; Bracht, A.; Schmit, B. S.; Fabian, A.; Pacheco, J. M.; Hartwig, E.; Berninger, M.; Carrillo, C.; Mayr, G.; Moran, K.; Kavanaugh, D.; Leibrecht, H.; White, W.; and Metwally, S., "Foot-and-Mouth Disease in Feral Swine: Susceptibility and Transmission" (2010). USDA National Wildlife Research Center - Staff Publications. 1068.

https://digitalcommons.unl.edu/icwdm_usdanwrc/1068

This Article is brought to you for free and open access by the U.S. Department of Agriculture: Animal and Plant Health Inspection Service at DigitalCommons@University of Nebraska - Lincoln. It has been accepted for inclusion in USDA National Wildlife Research Center - Staff Publications by an authorized administrator of DigitalCommons@University of Nebraska - Lincoln. 


\section{Authors}

F. Mohamed, S. Swafford, H. Petrowski, A. Bracht, B. S. Schmit, A. Fabian, J. M. Pacheco, E. Hartwig, M. Berninger, C. Carrillo, G. Mayr, K. Moran, D. Kavanaugh, H. Leibrecht, W. White, and S. Metwally 


\title{
Foot-and-Mouth Disease in Feral Swine: Susceptibility and Transmission
}

\author{
F. Mohamed ${ }^{1}$, S. Swafford ${ }^{2}$, H. Petrowski ${ }^{1}$, A. Bracht ${ }^{1}$, B. Schmit ${ }^{2}$, A. Fabian ${ }^{1}$, J. M.Pacheco ${ }^{3}$, \\ E. Hartwig ${ }^{3}$, M. Berninger ${ }^{1}$, C. Carrillo ${ }^{1}$, G. Mayr ${ }^{1}$, K. Moran $^{1}$, D. Kavanaugh ${ }^{4}$, H. Leibrecht ${ }^{1}$, \\ W. White ${ }^{1}$ and S. Metwally ${ }^{1}$ \\ ${ }^{1}$ USDA, APHIS, Veterinary Services, National Veterinary Services Laboratories, Foreign Animal Disease Diagnostic Laboratory, Greenport, \\ NY, USA \\ 2 USDA, APHIS, Wildlife Services, Fort Collins, CO, USA \\ 3 Plum Island Animal Disease Center, USDA, ARS, Greenport, NY, USA \\ ${ }^{4}$ USDA, APHIS, Wildlife Services, Athens, GA, USA
}

Keywords:

Feral swine; Foot-and-mouth disease; susceptibility; transmission

\section{Correspondence:}

S. Metwally. USDA, APHIS, National Veterinary Services Laboratories, Foreign Animal Disease Diagnostic Laboratory, Greenport, NY 11944, USA.

Tel.: +1 631323 3322;

Fax: +1 631323 3366;

E-mail: Samia.a.metwally@aphis.usda.gov

Received for publication August 31, 2010 doi:10.1111/j.1865-1682.2011.01213.x

\begin{abstract}
Summary
Experimental studies of foot-and-mouth disease (FMD) in feral swine are limited, and data for clinical manifestations and disease transmissibility are lacking. In this report, feral and domestic swine were experimentally infected with FMDV (A24-Cruzeiro), and susceptibility and virus transmission were studied. Feral swine were proved to be highly susceptible to A-24 Cruzeiro FMD virus by intradermal inoculation and by contact with infected domestic and feral swine. Typical clinical signs in feral swine included transient fever, lameness and vesicular lesions in the coronary bands, heel bulbs, tip of the tongue and snout. Domestic swine exhibited clinical signs of the disease within $24 \mathrm{~h}$ after contact with feral swine, whereas feral swine did not show clinical signs of FMD until $48 \mathrm{~h}$ after contact with infected domestic and feral swine. Clinical scores of feral and domestic swine were comparable. However, feral swine exhibited a higher tolerance for the disease, and their thicker, darker skin made vesicular lesions difficult to detect. Virus titration of oral swabs showed that both feral and domestic swine shed similar amounts of virus, with levels peaking between 2 to $4 \mathrm{dpi} / \mathrm{dpc}$ (days post-inoculation/days post-contact). FMDV RNA was intermittently detectable in the oral swabs by real-time RT-PCR of both feral and domestic swine between 1 and $8 \mathrm{dpi} / \mathrm{dpc}$ and in some instances until $14 \mathrm{dpi} /$ $12 \mathrm{dpc}$. Both feral and domestic swine seroconverted 6-8 dpi/dpc as measured by $3 A B C$ antibody ELISA and VIAA assays. FMDV RNA levels in animal room air filters were similar in feral and domestic swine animal rooms, and were last detected at $22 \mathrm{dpi}$, while none were detectable at 28 or 35 dpi. The FMDV RNA persisted in domestic and feral swine tonsils up to $33-36 \mathrm{dpi} / \mathrm{dpc}$, whereas virus isolation was negative. Results from this study will help understand the role feral swine may play in sustaining an FMD outbreak, and may be utilized in guiding surveillance, epidemiologic and economic models.
\end{abstract}

\section{Introduction}

Foot-and-mouth disease (FMD) is a highly contagious acute vesicular disease of cloven-hoofed domestic livestock and wildlife. The Foot-and-mouth disease virus
(FMDV) is classified within the Aphthovirus genus, family Picornaviridae. Seven distinct serotypes [O, A, C, South African Territories (SAT) 1, SAT 2, SAT 3 and Asia 1] have been identified serologically, and multiple subtypes exist within each serotype (Grubman and Baxt, 2004). 
The disease is characterized by vesicular lesions in the mouth, nares, muzzle, feet and teats. The manifestation of the disease and susceptibility varies depending on the animal species affected and the virulence of the virus strain. FMD is the most contagious animal disease known, and transmission occurs via contact with infected animals, all secretions and excretions including semen, animal products, aerosolized droplets, and mechanical vectors (Alexandersen et al., 2001). FMDV amplifies quickly, and it is estimated that one pig can produce up to 60-fold higher airborne virus per day than that from sheep and cattle (Alexandersen et al., 2003).

Foot-and-mouth disease represents a significant threat to the US livestock industry and wildlife. In case of an outbreak, introduction of FMD into susceptible wildlife or feral swine would further complicate eradication and control. It has been estimated that the United States has 5 million feral swine (Sus scrofa) inhabiting 38 states, and their numbers are increasing (Pimental, 2007; Wyckoff et al., 2009). Feral swine populations in the United States are comprised of a continuum of genetic diversity ranging from escaped domestic swine (Sus scrofa domesticus) to Eurasian wild boar (Sus scrofa scrofa) and the hybrids of these subspecies (Mayer and Brisbin, 1991). This genetic diversity may present unforeseen problems for wildlife management agencies because of possible population level variation in disease susceptibility as well as populationlevel traits that influence disease spread and maintenance. It has been assumed that feral swine are as susceptible to FMD as domestic swine, because wild boars are the common ancestors of both. However, this assumption has not been supported by adequate studies. The only published reports available which document the natural occurrence of FMD in wild pigs are from the former Soviet Union and the Caucasus (Hone, 1990). It has been suggested that the paucity of information of FMD in wild pigs may be because of a real lack of occurrence, a failure to report FMD outbreaks, or poor access to non-English literature (Hone, 1990).

A number of modelling studies have been conducted worldwide looking at the role feral swine may play in the spread and persistence of FMD upon entry into FMD-free countries (e.g. Pech and Hone, 1988; Pech and Mcllroy', 1990; Dexter, 2003; Doran and Laffan, 2005; Ward et al., 2007; Cowled and Garner, 2008). However, these studies relied mainly on scientific data generated by pathogenesis, and transmission studies in domestic swine, because of a lack of similar studies in feral swine.

Efficient management of a potential outbreak of FMD in feral swine would require early detection of the outbreak through adequate surveillance, and use of established response strategies to control an outbreak once it has been detected. Hence, an understanding of disease dynamics and virus shedding in feral swine populations and the potential of disease spread from feral swine to domestic swine are critical in developing countermeasures for disease control and eradication. Unfortunately, studies of FMD in feral swine are limited, and data for disease transmissibility and clinical manifestations do not exist. In an effort to begin filling the knowledge gaps, a study of FMD in feral swine was conducted to compare the susceptibility of feral swine to FMD with that of domestic swine, and to gain knowledge on virus shedding and transmission between feral and domestic swine.

\section{Materials and Methods}

Animals

Fifteen clinically healthy feral swine of both sexes, age 6-8 months and weighing 50-60 lbs, were acquired from a captive feral swine breeding facility in Michigan, USA. These feral swine were of predominantly Eurasian wild boar heritage and should represent that spectrum of feral swine genetics across the US (McCann, B., unpublished results, 2010). All feral swine were born and raised within the breeding facility and were fed corn and commercial pig feed. All animals were screened for pseudorabies, swine brucellosis, and swine influenza and were dewormed with ivermectin $0.27 \%$ injection (Ivomec $^{\circledR}$; Merial Limited, Duluth, GA, USA) prior to shipment.

Six clinically healthy male domestic Yorkshire swine, age 3 months and weighing 40-50 lbs, were acquired from a private research breeding facility. All animals were vaccinated against porcine circovirus, swine influenza, atrophic rhinitis and mycoplasma pneumonia and were pre-treated with oxytetracycline in feed prior to shipment.

All feral and domestic swine were acclimated for 2 weeks in the biosafety level three agriculture (BSL-3Ag) facility at Plum Island Animal Disease Center (PIADC, New York) where the experiments were performed. All Institutional Animal Care and Use Committee (IACUC) protocols, and conditions for BSL-3Ag were observed including maintaining negative pressure in the animal rooms and showering and changing clothes between rooms.

\section{The virus}

The FMDV used in this study was type A-24 Cruziero strain derived from cattle and amplified in domestic swine. The virus produced disease in domestic pigs at a dose of 100 PHID $_{50}$ (50\% pig heel bulb infectious dose; Pacheco, J, unpublished data). The virus was diluted immediately before inoculation in minimum essential medium with Earle's balanced salt solution. 
Table 1. Experimental design: feral and domestic swine were inoculated with FMDV in Groups 2, 3 and 4. Contact animals were then introduced $48 \mathrm{~h}$ post-inoculation and co-mingled for the duration of the experiment

\begin{tabular}{llr}
\hline & Treatment & \multicolumn{1}{l}{ ID\#s } \\
\hline Group 1 & Control Feral Swine & 3,18 \\
Group 2 & Inoculated Feral Swine & 8,16 \\
& Contact Domestic Swine & $74,75,76,77$ \\
Group 3 & Inoculated Feral Swine & 1,2 \\
& Contact Feral Swine & $5,6,9,11,13$ \\
Group 4 & Inoculated Domestic Swine & 78,79 \\
& Contact Feral Swine & $7,10,14,15$ \\
\hline
\end{tabular}

ID\#S, Animal Identification Numbers.

\section{Experimental design and challenge}

Initially, feral and domestic swine were divided into four groups in 4 BSL-3Ag rooms (Table 1). Group 1 consisted of two non-infected control feral swine; groups 2 and 3 consisted of two inoculated feral swine each, and group 4 consisted of two inoculated domestic swine. All swine were inoculated using the following procedure: animals were sedated using $0.04 \mathrm{ml} / \mathrm{kg}$ body weight TKX (Telazole ${ }^{\circledR}$ $2 \mathrm{mg} / \mathrm{kg}$, ketamine $2 \mathrm{mg} / \mathrm{kg}$, xylazine $4 \mathrm{mg} / \mathrm{kg}$ ) by intramuscular injection, and were then inoculated with $0.4 \mathrm{ml}$ of the virus suspension (described earlier); inoculation consisted of 4 intradermal injections of $0.1 \mathrm{ml}$ each within the left rear heel bulb, as previously described (Pacheco and Mason, 2010). Two days after inoculations, the contact swine were introduced: four contact domestic swine to group 2, four contact feral swine to group 3 and four contact feral swine to group 4. All contact animals were allowed direct contact with their respective group for the duration of the experiment. Blood and oral swabs were collected daily from 0 to $8 / 10$ days post-contact/post-inoculation (dpc/dpi) then at 12/14, 19/21, 26/28 and 33/ $35 \mathrm{dpc} / \mathrm{dpi}$. For sample collection, feral swine were sedated as described earlier. Oral swabs were obtained by sterile Dacron swabs (Fisher, Pittsburgh, PA, USA), which were immediately inserted into $3 \mathrm{ml}$ of Tris-buffered tryptose broth (TBTB) and kept at $-70^{\circ} \mathrm{C}$ until processing. All animals were monitored daily for body temperature and examined for clinical signs. Clinical scores (described elsewhere) were assigned at sample collection times. Animal rooms housing group 2, 3 and 4 were furnished with air sampling units. Air sampling was conducted for $24 \mathrm{~h}$ periods at 1-10 dpi then at 17, 22, 28 and 35 dpi as described elsewhere. At the termination of the experiment 33-36 dpc/dpi, animals were sedated with TKX then euthanized by intravenous injection of Pentobarbital (FatalPlus $^{\circledR}$, vorteck pharmaceuticals, Dearborn, MI, USA) at $1 \mathrm{ml} / 10 \mathrm{lbs}$, and necropsies were performed. At the time of necropsy, selected tissue samples were collected and either frozen at $-70^{\circ} \mathrm{C}$ or preserved in $10 \%$ neutral buffered formalin until processing. Animals that were moribund or that could not reach food or water were immediately euthanized and necropsied.

\section{Clinical scoring}

Clinical scoring was done subjectively according to the method described by Quan et al. (2004) with a range from 0 to 6 . Briefly, a score of zero was given if no clinical signs were present; a score of one was given if the animal was lame; a score of one was given for each foot containing an FMD lesion (a score of 4 was given if all $4 \mathrm{ft}$ were affected); and a score of one was given if an FMD lesion was present on either the mouth, tongue or snout. Clinical scores were then added for each animal to obtain the cumulative score. The maximum cumulative score per animal was 6 . Once a lesion appeared at a site, the site was scored 'positive' on all subsequent days, even if the lesion at that site had begun to heal.

\section{Virus titration}

Oral swab samples were vortexed, and $600 \mu \mathrm{l}$ per sample was transferred into separate Corning Costar ${ }^{\circledR}$ Spin- $\mathrm{X}^{\circledR}$ $0.45 \mu \mathrm{m}$ cellulose acetate membrane centrifuge tube filters (product \# 8162) for centrifugation at $5000 \mathrm{rpm}$ for 2 min. A tenfold dilution series $\left(10^{-1}\right.$ through $\left.10^{-5}\right)$ was prepared per sample in $1.2 \mathrm{ml}$ polypropylene tubes Linbro $^{\circledR}$ liquisystem (MP Biomedicals, Inc. Solon, OH, USA). Prior to inoculation, the cell culture media was removed from the 96-well plates previously seeded with secondary lamb kidney (LK) cells that were 75-100\% confluent and replaced with $100 \mu \mathrm{l} /$ well of Eagle's Minimal Essential Medium (MEM) supplemented with 4\% foetal bovine serum. The sample dilutions were transferred from the polypropylene tubes to the appropriate wells of the designated 96 -well plates (50 $\mu \mathrm{l} /$ well), four replicates per dilution. The plates were incubated at $37^{\circ} \mathrm{C}$ with $5 \pm 1 \% \mathrm{CO}_{2}$ and read for the presence of cytopathic effect (CPE) daily for 3 days. Spearman-Karber $50 \%$ endpoint viral titres were calculated $\left(10^{\mathrm{x}} / \mathrm{ml}\right)$.

\section{Virus isolation}

Tonsil sample suspensions were made as $10 \%(\mathrm{w} / \mathrm{v})$ in MEM by grinding in a Mixer Mill $\left(\mathrm{MM} 300^{\circledR}\right.$; Retsh, Inc., Newtown, PA, USA) followed by low-speed centrifugation and filtering with $0.45-\mu \mathrm{m}$ filters. Virus isolation (VI) was performed in LK cell cultures and was conducted in Costar 24-well culture plates. Approximately a $1: 3$ ratio of inoculum to total volume was used per well. Following 1-h adsorption of the samples, the cell layers were replenished 
with fresh media and plates were incubated at $37^{\circ} \mathrm{C}$ with $5 \% \mathrm{CO}_{2}$ for $72 \mathrm{~h}$. A second blind passage was carried out for $72 \mathrm{~h}$, and plates were examined daily for CPE.

\section{rRT-PCR assay}

Oral swab and tonsil tissue homogenate samples (prepared as explained in the virus isolation section) were analysed using real-time reverse transcription polymerase chain reaction (rRT-PCR). RNA was extracted from $140 \mu \mathrm{l}$ of the respective samples using the Qiagen RNeasy ${ }^{\circledR}$ extraction kit (Qiagen, Stanford, CA, USA), following the protocol for extraction of total RNA from animal tissues, provided by the manufacturer. RNA was eluted in $40 \mu \mathrm{l}$ of RNase-free water, and stored at $-70^{\circ} \mathrm{C}$ until the PCR test was performed. Samples were tested for the presence of nucleic acid of FMDV using oligonucleotide primers and probes targeting a conserved region of the 3D polymerase gene segment of the FMDV genome (Moniwa et al., 2007). All PCR master mixes were prepared using the QuantiTect Probe RT-PCR kit ${ }^{\circledR}$ (Qiagen), and PCR cycling conditions were performed on a Smart Cycler II ${ }^{\circledR}$ (Cepheid, Sunnyvale, CA, USA) as previously described (Moniwa et al., 2007). RT-PCR results were interpreted as positive if $\mathrm{CT}$ values were $<35$; $\mathrm{CT}$ values of zero or 35 and above were considered negative.

\section{Agar gel immunodiffusion}

An agar gel immunodiffusion (AGID) assay was used for the detection of antibodies to the non-structural 3D protein, the major component of the 'virus infection-associated antigen' (VIAA) of FMDV (McVicar and Sutmoller, 1970; Morgan et al., 1978; Newman et al., 1979). A batch of $0.6 \%$ agarose gel (agarose Type-II-A, Sigma ${ }^{\circledR}$, St Louis, MO, USA) was prepared with $0.86 \%$ sodium chloride in a sodium barbital buffer $(0.025 \mathrm{~m}$ Sodium 5,5-diethylbarbiturate, 0.437 м Glycine, $0.1 \% \mathrm{NaN}_{3}, \mathrm{pH} 7.8$ ), plated into petri dishes, and stored at $4{ }^{\circ} \mathrm{C}$. As needed, $45-\mu \mathrm{l}$-capacity wells were cut and aspirated from an agarose gel plate in a predetermined pattern of well clusters, a total of seven clusters per plate each consisting of a circle of six wells surrounding a central well. The 3D antigen was placed in the central well and a bovine reference serum, containing antibody to the $3 \mathrm{D}$ antigen, was added into the peripheral wells alternating with the test or control sera samples. Antigen positive control/reference sera, and weak positive control were produced at the PIADC, NY. Bovine calf serum was used as a negative control. Plates were placed in a humidified container and incubated at room temperature $\left(20-25^{\circ} \mathrm{C}\right)$ for 16 to $96 \mathrm{~h}$, after which the test and control wells were read and interpreted based on precipitin lines and points of identity.

\section{ABC ELISA}

The PrioCHECK ${ }^{\circledR}$ FMDV NS Antibody test ELISA kit (Prionics Lelystad B.V., The Netherlands, product code 7610450), was used according to the manufacturer's instructions for detection of antibodies to the highly conserved non-structural 3ABC protein of FMDV (Sorensen et al., 1998). The ELISA kit contains plates pre-coated with the FMDV $3 \mathrm{ABC}$ non-structural antigen captured by anti-3ABC monoclonal antibody (mAb). Test and control sera were added to plates and incubated overnight as directed, followed by the addition of a secondary $\mathrm{mAb}$ HRPO detector and substrate. Anti-3ABC antibodies, if present in sample sera, block the binding of the secondary mAb-HRPO detector thereby decreasing colour development. Results were determined based on percent inhibition (PI), whereas $<50 \%$ PI was considered negative, while $\geq 50 \%$ PI was considered positive.

\section{Histopathology}

Selected tissues were collected at necropsy and fixed in $10 \%$ NBF. Sections were routinely processed, paraffinembedded, cut at 4 micrometer and stained with haematoxylin and eosin (H\&E) for light microscopic examination.

\section{Air filters}

Air sampling was carried out using a NAVSEA Dry Filter Unit (DFU) model 1000 air pump developed by the Program Executive Office for Chemical Biological Defense (Washington, DC, USA). This machine operates at $120 \mathrm{~V}$ and is capable of generating an air flow of $8673 \mathrm{l} / \mathrm{h}$. Each machine has two individually stored Lockheed-Martin polyester filter disks $(1.0 \mu \mathrm{m}$ filter, diameter $47 \mathrm{~mm}$, Catalogue Number DFU-P-24; Lockheed Martin, Alexandria, VA, USA). The filters were replaced every $24 \mathrm{~h}$. The machines were placed in the centre against the wall in exactly the same location in each animal room. The animal rooms were of identical size, and the animals were allowed free movement in direct contact with the air-sampling machines.

Viral RNA was extracted using the Qiagen RNeasy method. Initially, all filters, regardless of material, were placed in a tube and soaked in RLT buffer with betamercaptoethanol. Acid-washed glass beads (106 and 425$600 \mu$ ) were added and the filters were macerated using a Retsch mixer mill MM400 ${ }^{\circledR}$ (Retsch, Inc., Newtown, PA, USA) for $3 \mathrm{~min}$ at 30 beats per second. In order to ensure the entire buffer was harvested, the tube was inverted and centrifuged for $10 \mathrm{~min}$ at $2500 \mathrm{rpm}$. Following this, the standard Qiagen RNeasy viral RNA 
extraction protocol was performed on the centrifuged liquid.

Quantitative Real-time RT-PCR (qRT-PCR) was carried out using primers and probe designed specifically for the 3-D polymerase region. Forward primer sequence: 5'-ACTGGGTTTTACAAACCTGTGA-3', reverse primer sequence: 5'-GCGAGTCCTGCCACGGA-3' (Invitrogen, Carlsbad, CA, USA), and a FAM-labelled probe 5'-TCCTTTGCACGCCGTGGGACT-3' (Applied Biosystems, Foster City, CA, USA) were employed. Primers were used at a final concentration of $50 \mu \mathrm{M}$, and the probe was used at $10 \mathrm{~nm}$ per $25.0 \mu \mathrm{l}$ reaction. The reaction was performed using the Taqman EZ RT-PCR Core Reagents (Applied Biosystems \#N808-0236) at the following volumes/concentrations per $25.0 \mu \mathrm{l}$ reaction; $5.0 \mu \mathrm{l}$ of $5 \times$ buffer, $2.5 \mu \mathrm{l}$ of $25 \mathrm{~mm} \mathrm{Mn} \mathrm{(OAc)})_{2}, 3.0 \mu \mathrm{l}$ dNTPs (combined $1: 1: 1: 1$ by volume), $1.0 \mu \mathrm{lTth}$, and $10.55 \mu \mathrm{l}$ $\mathrm{H}_{2} 0$. RNA template $(2.5 \mu \mathrm{l})$ was added per reaction. The reactions were performed on the Smart-Cycler II sequence detection system using the following cycling conditions: $60^{\circ} \mathrm{C}$ for $10 \mathrm{~min}$ followed by 45 cycles at $95^{\circ} \mathrm{C}$ for $2 \mathrm{~s}$, and $60^{\circ} \mathrm{C}$ for $30 \mathrm{~s}$. CT values obtained were converted to the number of RNA copies/1000 1 of air based on FMDV RNA-specific calibration curves developed with In Vitro-synthesized RNA.

\section{Results}

\section{Clinical signs}

Inoculated and contact feral and domestic swine had transient fever $\left(40-41^{\circ} \mathrm{C}\right)$ or no fever at all (Fig. 1). It is important to note that because of the aggressive nature of the feral swine, rectal temperatures were taken immediately after TKX sedation which could cause a small but not significant decrease in rectal temperature (data not shown). At $2 \mathrm{dpi}$, one inoculated feral swine (\#8) had a body temperature of $41^{\circ} \mathrm{C}$, lameness, and was non-weight bearing on the left front foot, which exhibited blanching of the coronary bands. At 3 dpi, 2 additional inoculated feral swine (\#2 and \#16) showed vesicular lesions and blanching of the coronary bands. By $5 \mathrm{dpi}$, all four inoculated feral swine had the maximum clinical score of 6 (Fig. 2) with vesicular lesions in the coronary bands, heel bulbs, mouth, tip of tongue or snout (Fig. 3). Three of four contact feral swine had clinical signs of FMD 2 days after direct contact with domestic swine and all animals had the maximum clinical score at $5 \mathrm{dpi}$ (Fig. 2). At 7 and $8 \mathrm{dpc}$, feral swine (\#10 and \#5) were severely lame and unable to stand and therefore both were euthanized at $8 \mathrm{dpc}$. Severely affected feral swine walked cautiously, often lifting the most affected leg as they moved. One individual (\# 5) was observed standing on his front feet only, while others were observed to lie down with their feet off the ground.
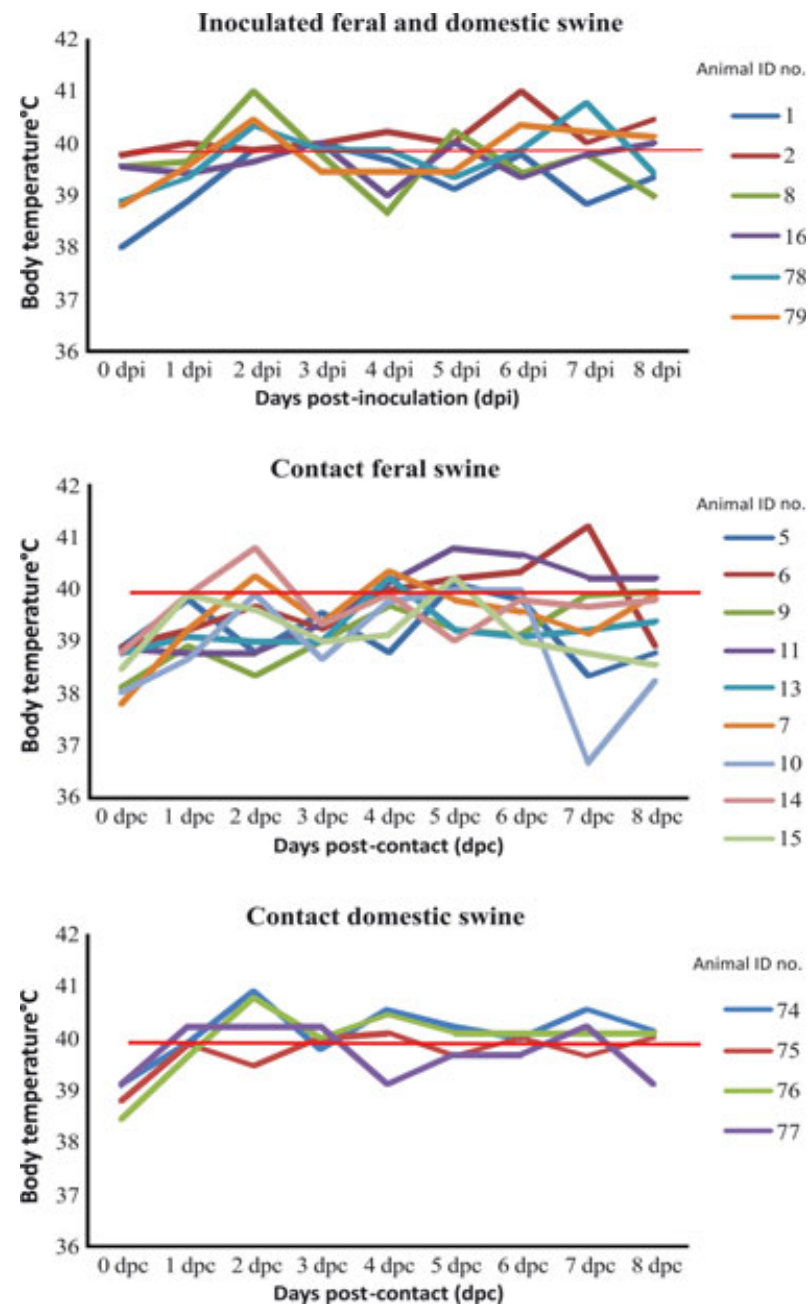

Fig. 1. Body temperature. The red horizontal line at $40^{\circ} \mathrm{C}$ represents the highest body temperature considered non-febrile. Please note that feral swine body temperature was measured immediately after sedation, which would cause slight drop in body temperature. Most animals had either low transient fever or no fever.

At $2 \mathrm{dpi}$, the two inoculated domestic swine (\#78 and \#79) were markedly lame, walking was difficult and they squealed when forced to move. Both individuals had vesicular lesions in the coronary bands of all $4 \mathrm{ft}$. Their heel bulbs were markedly swollen and they had body temperatures of $40.3-40.4^{\circ} \mathrm{C}$. At $3 \mathrm{dpi}$, ruptured vesicles were noted in the coronary bands, tongue and the tip of the lower lip. Within $24 \mathrm{~h}$ post-contact to inoculated feral swine, four contact domestic swine $(\# 74, \# 75$, \#76, and \#77) were markedly lame and unable to put weight on their rear feet, often squealing when forced to move. Coronary bands had vesicular lesions, and some ruptured (Fig. 4). At $2 \mathrm{dpc}$, contact domestic swine were severely lame and recumbent with more severe foot lesions than the inoculated feral in the same room. Abrasions and 

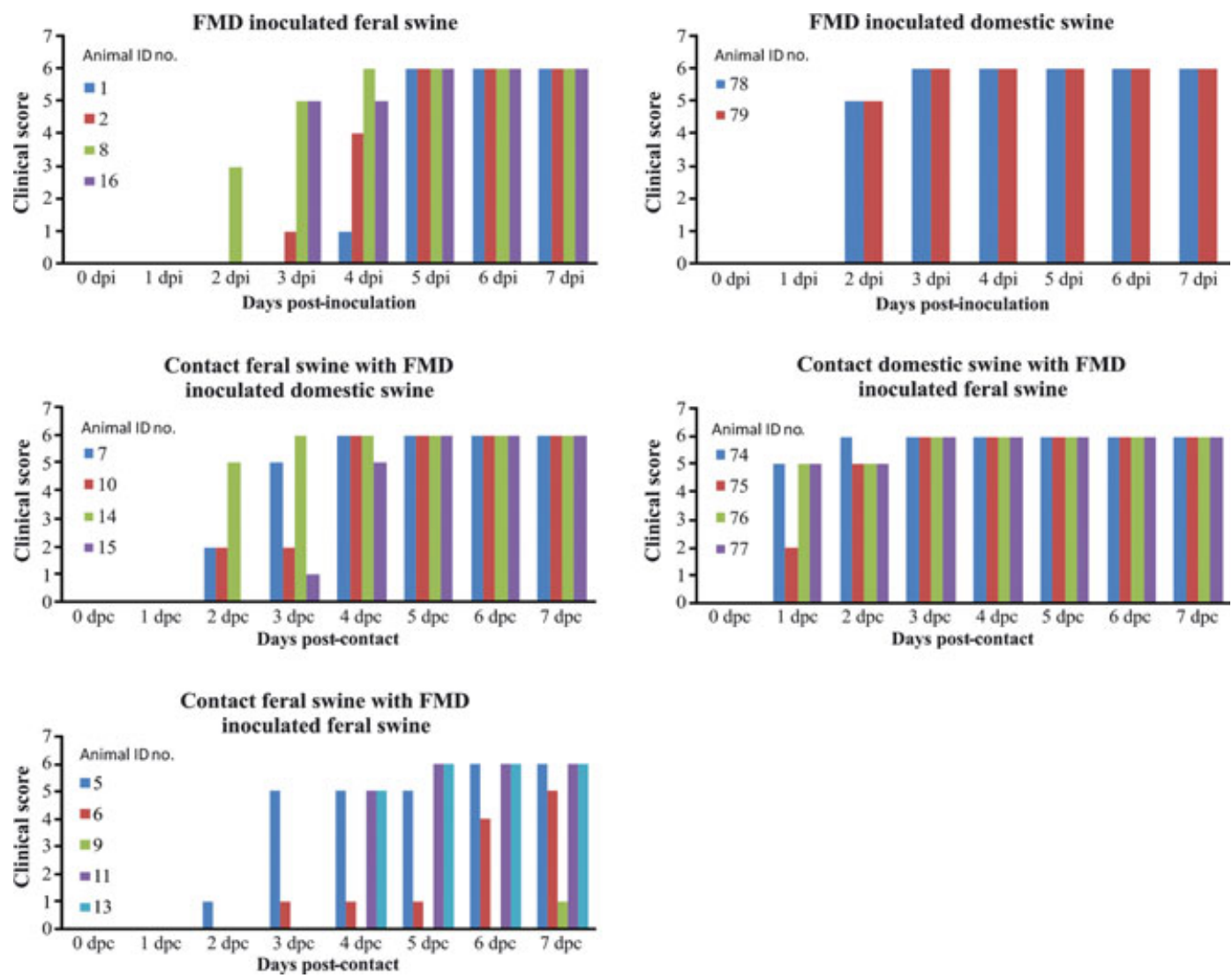

Fig. 2. Clinical scores. Clinical scores were determined as follows: 0 for no clinical signs; a score of 1 was given for lameness; a score of 1 was given for lesions in each foot (four were given if all feet were affected) and a score of 1 was given for lesions at any site in mouth, tongue or snout. Scores were then added to obtain a final clinical score. Six was the maximum score assigned.

ulcers were present on the tarsals and carpals skin from walking on these areas. At $4 \mathrm{dpc}$, all vesicular lesions had ruptured. At $6 \mathrm{dpc}$, contact domestic swine were severely lame and reluctant to move and all had sloughed at least $50 \%$ of their claws.

\section{Gross lesions}

Vesicular lesions on the heel bulbs of feral swine were hard to detect and often appeared as slight swelling and white discoloration (blanching) of the heel bulb skin (Fig. 5a). Palpation of the heel bulb sometimes revealed vesicular fluid accumulation in the heel bulb in the early stages of the disease. As the disease progressed, the heel bulb skin often peeled off leaving a raw red surface underneath. Vesicular lesions around the coronary bands were often obscured by the long black hair of feral swine (Fig. 3d). Occasionally, one solitary vesicular lesion with a thick capsule was present along the coronary band (Fig. 5a and b). Vesicular lesions, often with a thick capsule, were also found on the tip of the snout, tip of the lower lip and tip of the tongue (Fig. $3 a$ and b). Lesions on the tip of the tongue appeared as $1-2 \mathrm{~cm}$ circular white dry vesicles, which healed quickly within 1 week.

In contrast, domestic swine heel bulb and coronary band vesicular lesions were easily detected. The thin epidermis and light colour in domestic swine revealed the accumulation of vesicular fluid (Fig. 4b). Vesicular lesions also tended to rupture much easier in domestic swine than feral swine because of the thinner epidermis. Secondary bacterial infections and abscessation in the heel bulbs of both feral and domestic swine were observed, which significantly delayed the healing process. Severe skin abrasions of the carpals and tarsals were often observed, most commonly in domestic swine, as affected pigs rested on their carpals and tarsals to relieve heel bulb pain. In both domestic and feral swine, the claws sloughed, though at a much lower incidence in feral swine. When not sloughing, a line of separation appeared between old and new claws moving steadily downwards from the coronary bands (Figs $4 \mathrm{~d}$ and $5 \mathrm{~d}$ ). 

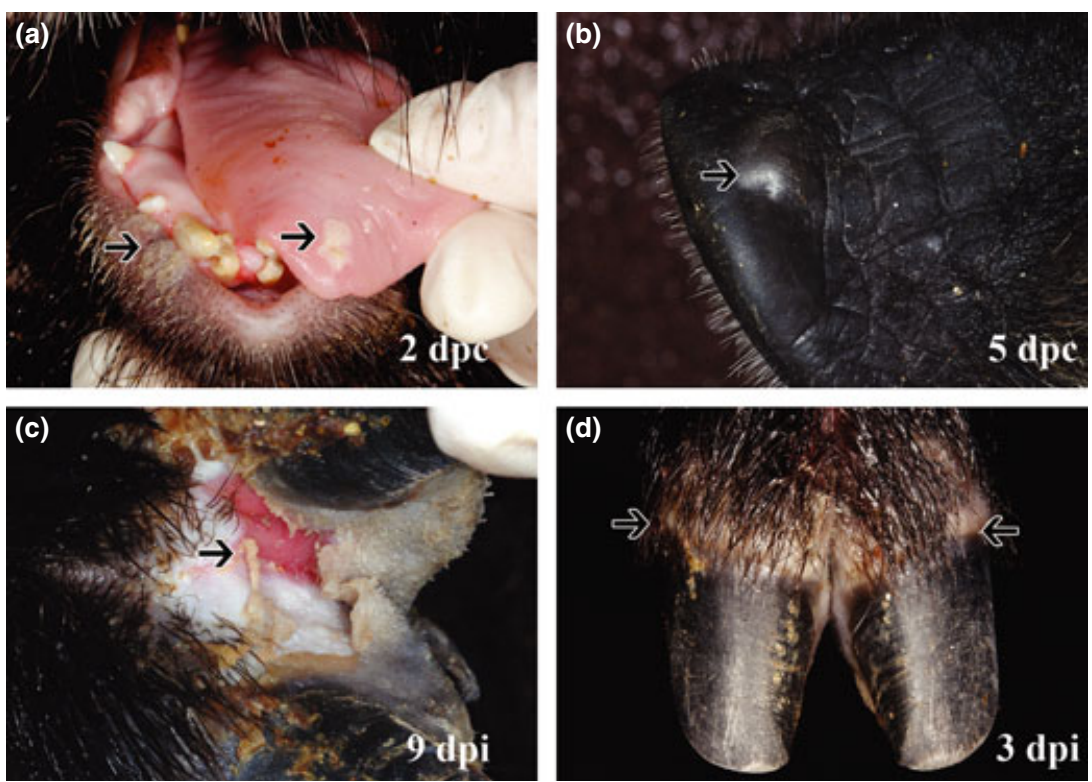

Fig. 3. (a-d) Common lesions in FMD infected feral swine. Note a small dry vesicle at the tip of the tongue and dry vesicular lesions at the lower lip $2 \mathrm{dpc}$ (arrows; a). A thick-walled solitary vesicle at the tip of the snout $5 \mathrm{dpc}$ (arrow; b) Ruptured interdigital vesicle revealing a raw surface 9 dpi (arrow; c). Vesicular lesions along the coronary bands masked by the long black hair of feral swine 3 dpi (arrows; d).
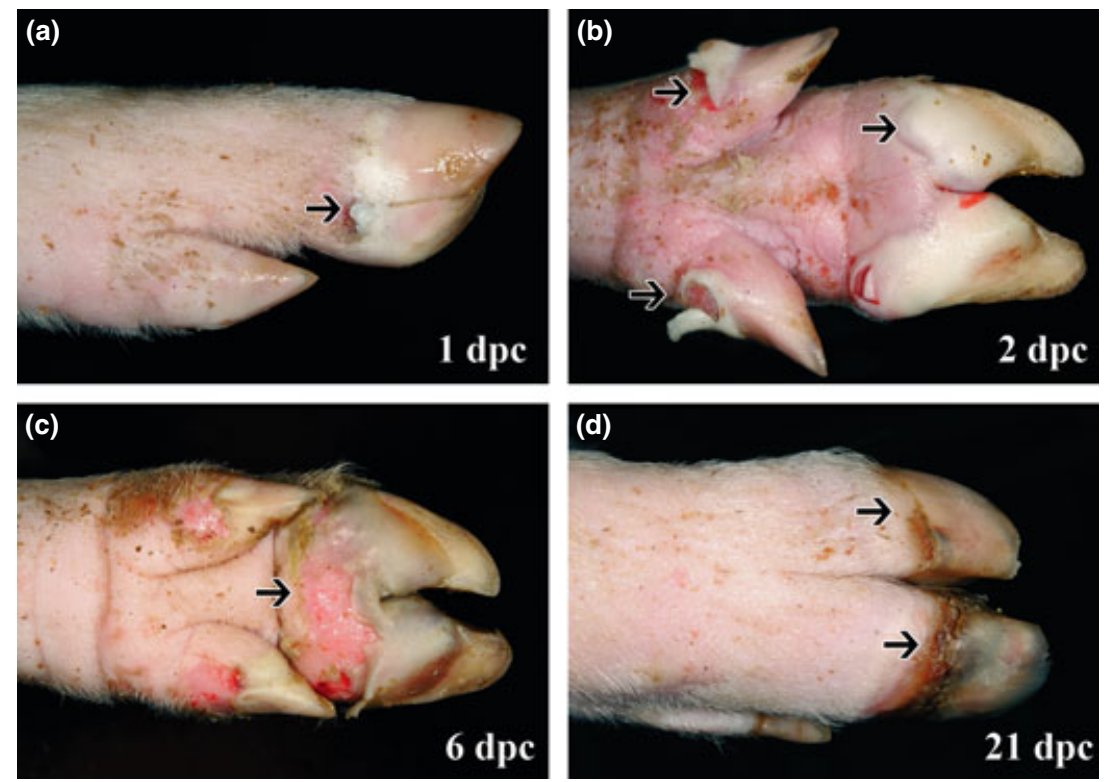

Fig. 4. (a-d) FMD foot lesions in domestic swine. Note ruptured vesicle in the coronary band (arrow) 1 dpc (day post-contact) with inoculated feral swine (a). Ruptured and full-blown vesicular lesions in the heel bulb and the coronary bands of the accessory claws at 2 dpc (arrows; b). Completely ruptured vesicle in the heel bulb $6 \mathrm{dpc}$ (arrow; c). New claw growing distally from the coronary bands $21 \mathrm{dpc}$ (arrows; d).

\section{Histopathology}

Histopathological lesions of the heel bulb and coronary bands were examined at $8 \mathrm{dpc}$ in two feral swine and were characterized by severe disruption of the stratum spinosum, because of ballooning degeneration and acantholytic changes of keratinocytes (Fig. 6a and b). Large clefts, presumably filled with vesicular fluid, appeared at the middle of the stratum spinosum but often extended to just above the stratum basale. Occasionally, the startum basale was also disrupted. Aggregates of neutrophils and colonies of bacterial coccobacilli were 

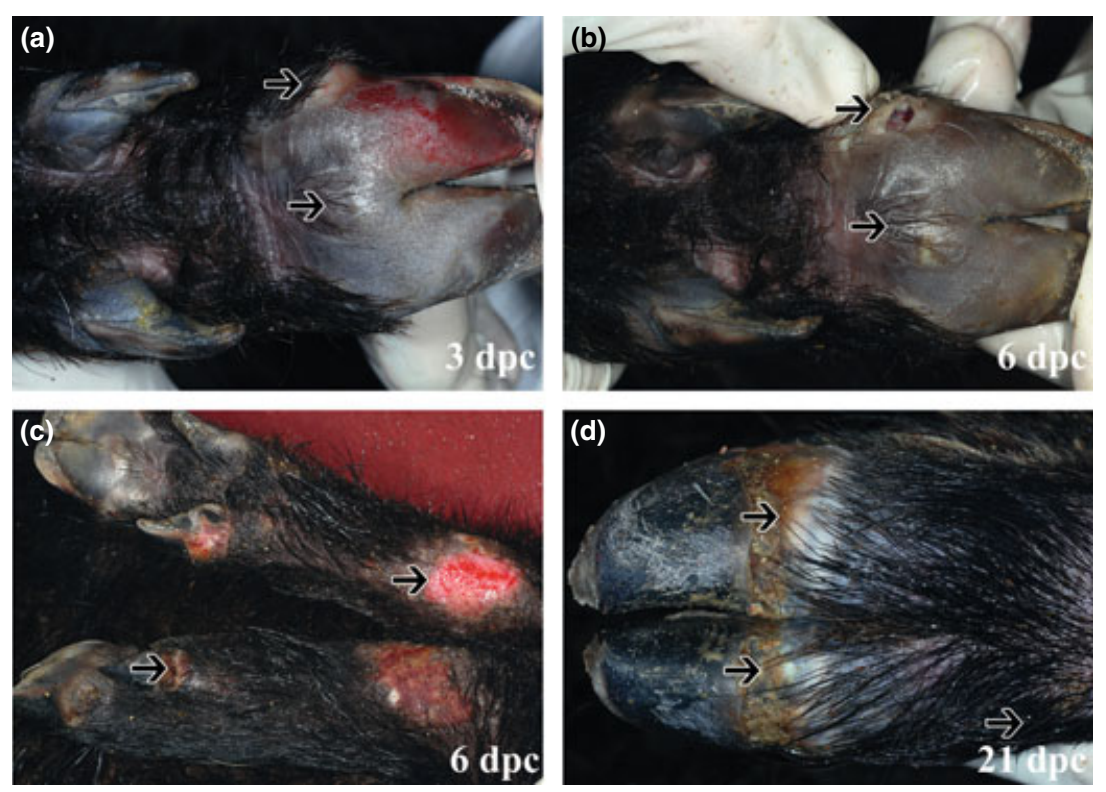

Fig. 5. (a-d) FMD foot lesions in feral swine. Note swelling of the heel bulb and development of a solitary thick-walled vesicle on the coronary band $3 \mathrm{dpc}$ (arrows; a). Rupture of the same vesicle in Fig 5a, at $6 \mathrm{dpc}$ and shrinkage of the swelling of the heel bulb (arrows; b). Note ruptured vesicles on the coronary bands and severe abrasions of the tarsals $6 \mathrm{dpc}$ (arrows; c). New claws growing distally from the coronary bands $21 \mathrm{dpc}$ (arrows; d).

observed within the disrupted stratum spinosum indicating secondary bacterial infection (Fig. 6a). The thick keratinized layer overlying the disrupted stratum spinosum of the heel bulb often appeared intact. The superficial dermis was infiltrated with lymphocytes and plasma cells.

\section{Virus titration in oral swabs}

Virus titre in oral swabs varied widely between individual animals. However, all domestic and feral swine had virus titres $>3.8 \mathrm{TCID} 50 / \mathrm{ml} \log 10$ within the first week of inoculation or contact with infected swine (Tables 2 and 3). Overall, peak levels of virus shed by domestic and feral swine were similar ranging from 3.8 to 5.0 TCID $50 / \mathrm{ml}$ $\log 10$. Neither feral nor domestic swine had detectable virus titre in the oral swabs beyond $10 \mathrm{dpi} / 8 \mathrm{dpc}$, with the exception of one feral swine (\#16) which had a titre of $1.05 \mathrm{TCID} 50 / \mathrm{ml} \log 10$ at $14 \mathrm{dpi}$. Most inoculated feral and domestic swine exhibited the highest viral titres in oral swabs at $2 \mathrm{dpi}$, while contact animals showed highest
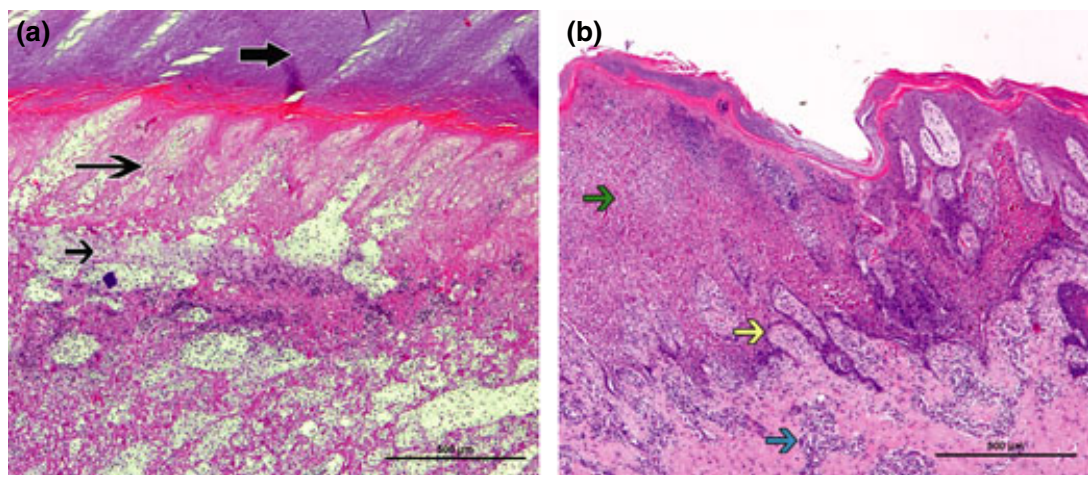

Fig. 6. ( $a$, b) Histopathology of FMD-infected feral swine heel bulb (a) and coronary band (b) at $8 \mathrm{dpc}$. Heel bulb. Note disruption of the stratum spinosum (long arrow) and development of clefts filled with vesicular fluid and infiltration of neutrophils (short arrow). The overlying stratum corneum (thick arrow) remains intact (a). Coronary band. The stratum spinosum shows marked acantholytic degeneration and necrosis (green arrow) with remaining intact stratum basale (yellow arrow). Mild perivacular infiltration of lymphocytes and plasma cells is observed in the superficial dermis (blue arrow; b). Haematoxylin and eosin. 
Table 2. Comparison of FMDV rRT-PCR and virus titration results of oral swabs from control and inoculated feral and domestic swine (expressed as positive or negative rRT-PCR results/virus titration as $T C I D_{50} / \mathrm{ml} \log _{10}, 0$ indicates no virus found)

\begin{tabular}{|c|c|c|c|c|c|c|c|c|}
\hline \multirow[b]{2}{*}{ DPI } & \multicolumn{2}{|c|}{ Control Feral (ID\#) } & \multicolumn{4}{|c|}{ Inoculated Feral (ID\#) } & \multicolumn{2}{|c|}{$\begin{array}{l}\text { Inoculated Domestic } \\
\text { (ID\#) }\end{array}$} \\
\hline & 3 & 18 & 16 & 8 & 1 & 2 & 78 & 79 \\
\hline 0 & -10 & -10 & -10 & -10 & -10 & -10 & -10 & -10 \\
\hline 1 & -10 & $-/ 0$ & -10 & -10 & $-/ 1.05$ & $+/ 2.3$ & $+/ 4.05$ & $+/ 3.8$ \\
\hline 2 & -10 & $-/ 0$ & $+/ 4.8$ & $+/ 4.3$ & $+/ 4.3$ & $-/ 3.8$ & $+/ 3.05$ & $+/ 4.05$ \\
\hline 3 & -10 & -10 & $+/ 3.8$ & $+/ 2.55$ & $+/ 3.55$ & $+/ 2.8$ & $+/ 2.05$ & $+/ 2.05$ \\
\hline 4 & $-/ 0$ & -10 & $+/ 3.05$ & $+/ 3.8$ & -10 & $+/ 0$ & $+/ 3.55$ & $+/ 2.55$ \\
\hline 5 & -10 & $-/ 0$ & $+/ 1.3$ & $+/ 2.05$ & -10 & $-/ 2.05$ & $+/ 1.05$ & $-/ 1.05$ \\
\hline 6 & $-/ 0$ & $-/ 0$ & -10 & $-/ 0$ & $-/ 2.05$ & $+/ 1.05$ & $+/ 0$ & $-/ 1.55$ \\
\hline 7 & -10 & -10 & -10 & $+/ 1.05$ & $-/ 1.3$ & -10 & $+/ 4.3$ & $+/ 2.05$ \\
\hline 8 & -10 & $-/ 0$ & -10 & -10 & $-/ 0$ & -10 & -10 & -10 \\
\hline 9 & -10 & $-/ 0$ & -10 & $-/ 1.3$ & $-/ 0$ & $-/ 0$ & -10 & -10 \\
\hline 10 & -10 & -10 & $-/ 1.05$ & $+/ 1.3$ & -10 & -10 & -10 & -10 \\
\hline 14 & $-/ 0$ & -10 & $+/ 1.05$ & $-/ 0$ & -10 & -10 & -10 & -10 \\
\hline 21 & -10 & $-/ 0$ & -10 & $-/ 0$ & $-/ 0$ & -10 & $-/ 0$ & -10 \\
\hline 28 & -10 & -10 & -10 & -10 & -10 & -10 & -10 & -10 \\
\hline 35 & $-/ 0$ & -10 & -10 & -10 & $-/ 0$ & -10 & -10 & -10 \\
\hline
\end{tabular}

ID\#, Animal Identification number; DPI, Days Post-Inoculation.

Table 3. Comparison of FMDV rRT-PCR and virus titration results of oral swabs from contact feral and domestic swine (expressed as positive or negative rRT-PCR results/virus titration as $T C D_{50} / \mathrm{ml} \log _{10}, 0$ indicates no virus found)

\begin{tabular}{|c|c|c|c|c|c|c|c|c|c|c|c|c|c|}
\hline \multirow[b]{2}{*}{ DPC } & \multicolumn{9}{|c|}{ Contact Feral (ID\#) } & \multicolumn{4}{|c|}{ Contact Domestic (ID\#) } \\
\hline & 13 & 5 & 11 & 9 & 6 & 10 & 7 & 14 & 15 & 74 & 75 & 76 & 77 \\
\hline 0 & -10 & -10 & -10 & -10 & -10 & -10 & -10 & -10 & -10 & -10 & -10 & -10 & -10 \\
\hline 1 & $-/ 1.05$ & $+/ 2.05$ & -12.3 & $+/ 3.05$ & $+/ 2.3$ & -10 & -10 & $-/ 1.05$ & -10 & $-/ 1.3$ & $-/ 1.55$ & $+/ 2.3$ & $-/ 1.05$ \\
\hline 2 & $+/ 2.3$ & $+/ 1.05$ & $+/ 4.05$ & -10 & -10 & $+/ 2.55$ & $+/ 3.05$ & $+/ 4.55$ & $+/ 1.8$ & $+/ 5.05$ & $+/ 3.8$ & $+/ 3.8$ & $+/ 4.3$ \\
\hline 3 & $+/ 5.05$ & $-/ 1.3$ & $+/ 4.05$ & $+/ 4.3$ & $+/ 4.3$ & $+/ 2.3$ & $+/ 3.55$ & $+/ 2.55$ & $+/ 4.55$ & $+/ 2.3$ & $+/ 1.8$ & $+/ 2.8$ & $+/ 4.55$ \\
\hline 4 & $+/ 2.8$ & $+/ 4.05$ & $+/ 2.8$ & $+/ 2.8$ & $+/ 3.55$ & $+/ 4.8$ & $+/ 3.8$ & $+/ 2.05$ & $+/ 4.3$ & $+/ 0$ & $+/ 1.3$ & $+/ 1.05$ & $+/ 1.05$ \\
\hline 5 & $+/ 1.3$ & $+/ 3.8$ & $+/ 2.55$ & $+/ 1.8$ & $+/ 3.8$ & $+/ 2.3$ & $+/ 1.05$ & $+/ 1.8$ & $+/ 3.8$ & $+/ 0$ & $+/ 0$ & $+/ 0$ & $+/ 1.3$ \\
\hline 6 & -10 & $+/ 2.05$ & $+/ 2.3$ & $+/ 3.05$ & $+/ 2.8$ & $+/ 1.8$ & $+/ 0$ & $+/ 0$ & $+/ 1.55$ & $+/ 0$ & $+/ 0$ & $+/ 0$ & $+/ 2.55$ \\
\hline 7 & -10 & -10 & $+/ 1.05$ & $+/ 1.05$ & $+/ 0$ & $+/ 0$ & -10 & -10 & $+/ 0$ & -10 & $+/ 1.05$ & $+/ 0$ & $+/ 0$ \\
\hline 8 & $+/ 0$ & -10 & $+/ 0$ & $+/ 0$ & $+/ 0$ & $+/ 0$ & -10 & -10 & $+/ 0$ & -10 & $+/ 0$ & $+/ 1.3$ & $+/ 1.05$ \\
\hline 12 & -10 & Euth & $+/ 0$ & -10 & -10 & Euth & -10 & -10 & -10 & -10 & $+/ 0$ & $+/ 0$ & -10 \\
\hline 19 & -10 & & -10 & -10 & -10 & & -10 & -10 & -10 & -10 & -10 & -10 & -10 \\
\hline 26 & -10 & & -10 & -10 & -10 & & -10 & -10 & -10 & -10 & -10 & -10 & -10 \\
\hline 33 & -10 & & -10 & -10 & -10 & & -10 & -10 & -10 & -10 & -10 & -10 & -10 \\
\hline
\end{tabular}

ID\#, Animal Identification number; DPC, Days Post-Contact; Euth, Euthanized.

viral shedding between 2 and $4 \mathrm{dpc}$, with the levels in contact domestic swine peaking earlier than in contact feral swine.

\section{rRT-PCR of oral swabs}

One of the four inoculated feral swine had an rRT-PCRpositive oral swab at $1 \mathrm{dpi}$, while two of two inoculated domestic swine also had rRT-PCR-positive oral swabs at $1 \mathrm{dpi}$. The three remaining inoculated feral swine became positive by 2 dpi. All inoculated feral and domestic swine oral swabs were positive by rRT-PCR from 2 to 4 dpi with two exceptions: feral swine \# 1 was positive for only 2 days, whereas feral swine \#2 was positive intermittently through 6 dpi. Beyond 4 dpi, most inoculated swine showed only intermittent detection of viral RNA, the latest detection occurring at $14 \mathrm{dpi}$ in inoculated feral swine \#16 (Table 2).

Three of nine contact feral swine were positive by rRTPCR at $1 \mathrm{dpc}$, while one of four domestic swine was positive at $1 \mathrm{dpc}$. The remaining contact feral and domestic 
swine showed positive results on 2 dpi. With few exceptions, most contact feral and domestic swine continued to have positive rRT-PCR oral swabs through $6 \mathrm{dpc}$. One feral swine (\#11) and two domestic (\#75 and \#76) had positive rRT-PCR through $12 \mathrm{dpc}$ (Table 3 ).

\section{Serology}

Seroconversion of both feral and domestic swine consistently occurred between 6 and $8 \mathrm{dpi} / \mathrm{dpc}$ measured by the 3 ABC ELISA (Fig. 7). VIAA assay produced similar results with more than $98 \%$ (275/279 samples) agreement between the two tests (results not shown).

\section{VI and rRT-PCR in tonsils}

At the termination of the experiment at 33-36 dpi/dpc, or when animals had to be euthanized, the tonsils were collected and tested for the presence of FMDV using rRT-PCR and virus isolation. Virus isolation in LK cells was negative for all tonsils after two blind passages of 3 days duration each. In contrast, when tested by rRT-PCR 16 of 19 tonsils taken from exposed feral and domestic swine (84\%) showed positive results for FMDV RNA (Table 4).

\section{Air filters results}

The highest FMDV RNA copy number of 6 per 10001 of air was detected at $5 \mathrm{dpi}$ in the inoculated feral/contact domestic swine (group 2) and at $2 \mathrm{dpi}$ in each of the other two groups (inoculated feral/contact feral (group 3) and the inoculated domestic/contact feral (group 4). FMDV RNA was detected in air filters in all three rooms within the time frame $1-10,1-17$ and $1-22 \mathrm{dpi}$, in groups 2, 3 and 4, respectively (Fig. 8). At 5 and $10 \mathrm{dpi}$, no FMDV RNA was detected in group 3 and 4 rooms, respectively. The exact reason for negative results at these time points has not been determined; however, RT-PCR inhibitors or sampling variations may account for effects seen especially when there are low levels of target virus. Overall there was no significant difference in the amount of FMDV RNA detected in the air filters between the 3 groups, which ranged between 3 and 6 FMDV RNA copy number/1000 1 of air within the first 9 days of the experiment. It is important to note that group 3 was an all feral swine room and had comparable amount of FMD RNA detected as the other two groups, which were mixed domestic and feral swine. No FMDV RNA was detected in any of the rooms at 28 and 35 dpi (Fig. 8).

\section{Discussion}

Feral swine were shown to be susceptible to A-24 Cruziero FMDV by inoculation and by contact to both infected feral and domestic swine. Typical clinical signs in feral swine in this study included transient fever, lameness $(100 \%)$, and vesicular lesions in the coronary bands, heel bulbs, tip of the tongue, tip of the lower lip and snout. Heel bulb lesions appeared as swelling, softening and white discoloration (blanching) of the heel bulbs, which

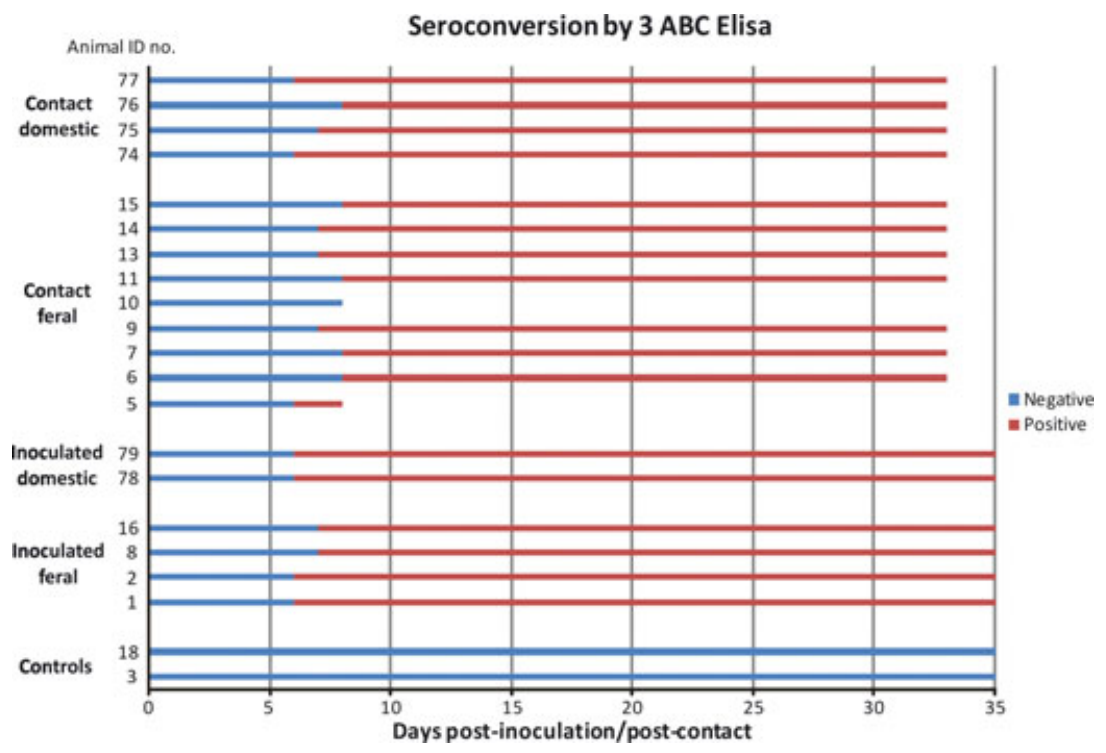

Fig. 7. Serology: $3 A B C$ antibody ELISA of FMD inoculated and contact feral and domestic swine. Each bar represents an individual animal. Domestic and feral swine seroconverted between 6 and $8 \mathrm{dpi} / \mathrm{dpc}$. Note that feral swine numbers 5 and 10 were euthanized at 8 dpc. The two control feral swine did not seroconvert as expected. 
Table 4. FMD Virus isolation and rRT-PCR results of feral and domestic swine tonsils at conclusion of experiment

\begin{tabular}{|c|c|c|c|c|}
\hline Treatment & ID\#S & DPI/DPC & VI $(+/ n)$ & rRT-PCR (+/n) \\
\hline Control Feral Swine & 3,18 & 35 & $0 / 2$ & $0 / 2$ \\
\hline Inoculated Feral Swine & 8,16 & 36 DPI & $0 / 2$ & $1 / 2$ \\
\hline Contact Domestic Swine & $74,75,76,77$ & $34 \mathrm{DPC}$ & $0 / 4$ & $4 / 4$ \\
\hline Inoculated Feral Swine & 1,2 & 36 DPI & $0 / 2$ & $2 / 2$ \\
\hline Contact Feral Swine & $5 *, 6,9,11,13$ & 33 DPC & $0 / 5$ & $5 / 5$ \\
\hline Inoculated Domestic Swine & 78,79 & 36 DPI & $0 / 2$ & $0 / 2$ \\
\hline Contact Feral Swine & $7,10 *, 14,15$ & 34 DPC & $0 / 4$ & $4 / 4$ \\
\hline
\end{tabular}

VI, Virus isolation on Lamb Kidney Cells, passage 2; (+/n), Number of positive animals over total number tested; DPI, Days Post-Inoculation; DPC, Days Post-Contact; ID\#s, Animal Identification Numbers.

*Animals \#5 and \#10 were euthanized, samples for VI/rRT-PCR were taken at 8 DPC.

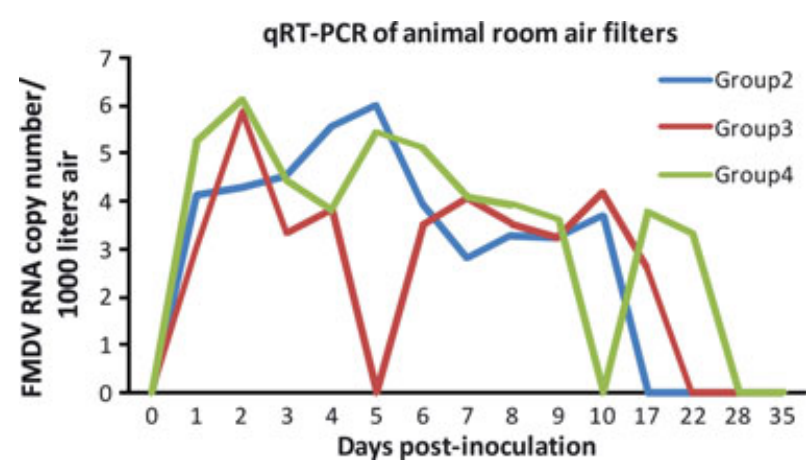

Fig. 8. Quantitative real time RT-PCR of air filters expressed as FMDV RNA copy number per 1000 I of air. Note that at day 5 and 10, no RNA was detected for group 3 and 4, respectively. No RNA was detected at 28 and $35 \mathrm{dpi}$ in any of the 3 group rooms. (Group 2: Inoculated feral/contact domestic; Group 3: Inoculated feral/contact feral; Group 4: Inoculated domestic/contact feral). Refer to Table 1 for animal numbers per group. Note that at day 10 , one animal was euthanized from each of group 3 and 4 .

was sometimes difficult to detect. Squealing sounds, often noted in domestic swine when attempting to put weight on their affected feet, were not observed in feral swine. Overall, clinical signs took longer to appear and were harder to detect in feral swine as compared to domestic swine. For example, all contact domestic swine became lame and showed vesicular lesions within $24 \mathrm{~h}$ after contact with inoculated feral swine, whereas the feral swine, when exposed to either inoculated domestic or feral swine, did not show clinical signs until $2 \mathrm{dpc}$. It is interesting to note that onset of clinical signs in domestic swine occurred more quickly via direct contact with inoculated feral swine than by direct inoculation with FMDV.

Disease detection also proved to be more difficult in feral swine because vesicular lesions were often masked by their thicker skin. Coronary bands lesions were often obscured by their long course dark hair, and in general feral swine exhibited higher tolerance to the disease. The increased difficulty in detecting clinical signs in feral swine may have important implications for observational surveillance programs, which are often based on clinical detection.

The difference in gross lesions between feral and domestic swine can mainly be attributed to the thicker skin in feral swine. Although feral and domestic swine used in this experiment were matched for body weight, it is unclear whether the difference in age may have played a role. Large bulging vesicles typically developed in the heel bulbs of domestic swine but were not observed in feral swine. Feral swine mainly exhibited slight swelling of the heel bulb where aspiration revealed accumulation of vesicular fluid. Feral swine occasionally developed solitary vesicular lesions with thick capsules along the coronary bands, a feature not observed in domestic swine.

Virus titration of oral swabs showed that feral and domestic swine shed similar quantities of virus and were equally capable of transmitting the virus to their contacts. Generally, virus shedding in the saliva appeared to cease at 6,7 and $8 \mathrm{dpi} / \mathrm{dpc}$, with a few notable exceptions in which virus was detected up to 14 dpi. Oral swabs were positive by rRT-PCR 1-2 dpi/dpc in all feral and domestic swine indicating that these animals shed virus in their saliva soon after they were infected and often before showing clinical signs of the disease. RT-PCR and virus titration results of oral swabs showed occasional intermittent and inconsistent results where a sample was positive in one test and negative on the other. RT-PCR is expected to have higher sensitivity than virus isolation; however, unknown tissue-derived factors may inhibit RT-PCR (Hoffmann et al., 2009) It is also generally known that neutralizing antibodies in the saliva could interfere with virus recovery as shown in cattle (Salt et al., 1996).

There was no significant difference in the amount of FMDV RNA detected in air filters between the three groups; however, it is difficult to make direct comparisons between feral and domestic swine because feral and domestic swine were mixed in group 2 and 4 and animal 
numbers slightly varied (Table 1). It was not clear why the time frame, in which FMDV RNA was detected in air filters, varied between the three groups at 1-10, 1-17 and 1-22 dpi, but this was most likely due to the cumulative individual animal variations. It can also be concluded that no virus shedding occurred past day $22 \mathrm{dpi}$ in any of the three group rooms. It should be noted however, that detection of FMDV RNA in air filters, though indicative of viral shedding, does not confirm the presence of live virus in the air filters.

An FMD carrier animal has been defined as one in which the presence of FMDV can be detected for more than 28 days after infection (Alexandersen et al., 2003). By this definition, ruminants have been classified as potential carriers of FMD infection, whereas pigs have been shown by virus isolation and RT-PCR to clear the virus within 3-4 weeks after infection indicating that they would not be FMD carriers (Alexandersen et al., 2003). Results from the present study, however, showed that FMDV RNA was detectable in the tonsils of $84 \%$ of infected feral and domestic swine by rRT-PCR at the termination of the experiment at 33-36 dpi/dpc. These results support and extend other study findings where FMDV was isolated from the tonsils of pigs up to $26 \mathrm{dpc}$ (Carrillo et al., 2007) and FMDV RNA was detected in the tonsils of infected swine until 28 dpi (Orsel et al., 2008; Zhang and Bashiruddin, 2009). Virus isolation in LK cells, on the other hand, failed to detect FMDV in the tonsils at 33-36 dpi/dpc, and therefore, the presence of live virus can not be confirmed. It is important to note that tonsil samples were not treated prior to cell culture to help dissociate the virus/antibody complexes, which could have increased the possibility of recovering live virus (Kitching, 2002). In light of our findings and others (Mezencio et al., 1999; Orsel et al., 2008; Zhang and Bashiruddin, 2009), the question of carrier state in pigs should be further investigated. In agreement with our findings in feral and domestic swine, it is interesting to note that FMDV antigen or viral RNA was also reported to persist in lymphoid tissue in cattle, swine and sheep (Kitching and Hughes, 2002; Juleff et al., 2008; Zhang and Bashiruddin, 2009).

Similar to other species, the best chance for an accurate diagnosis of FMD in feral swine is to use a combination of tests such as virus isolation, antigen ELISA, PCR and serology. According to our findings, the window of detection by virus isolation and PCR in oral swabs was narrow, and serology, using 3 ABC ELISA and VIAA assays, may not yield positive results until 6-8 days after infection. This finding has significant implications regarding disease surveillance and management suggesting that serological testing combined with antigenic detection is the most appropriate approach.
Disease surveillance strategies in wildlife have been recommended to target high-risk populations. With regard to feral swine, observational surveillance would largely be dependent on the recognition of an outbreak of lameness, as this is the most outwardly visible manifestation of the disease. However, lameness in wildlife is often unnoticed and unreported because of animal behaviour and habitat limitations. Closer examination, usually after sedation or euthanasia, is needed to characterize the type of lameness and to look for other clinical signs of FMD such as fever (though transient), and vesicular lesions on the tongue, coronary bands, foot bulbs or the snout. Laboratory tests such as virus isolation, antigen ELISA, RT-PCR and antibody ELISA are essential to detect and confirm FMD and differentiate it from other vesicular diseases such as vesicular stomatitis, swine vesicular disease and vesicular exanthema of swine. The commercially available non-structural 3 ABC ELISA (PrioCHECK ${ }^{\circledR}$ ) employed in this study was comparable to the Panaftosascreening index method described in the Diagnostic Manual of the World Animal Health Organization (OIE; Brocchi et al., 2006). These assays have the advantage of identifying all FMD serotypes and differentiating between vaccinated and naturally infected animals. The VIAA assay, which is based on detection of antibody to $3 \mathrm{D}$ non-structural RNA polymerase, produced similar results in this study. However, the 3D non-structural RNA polymerase is relatively conserved across picornaviruses and can potentially give false-positive results if other picornaviruses are involved (Robertson et al., 1983). According to this study, feral and domestic swine seroconverted 6-8 dpi/dpc measured by 3 ABC ELISA and VIAA assays. It is therefore anticipated that these tests will not detect acute FMD if conducted $<6-8$ days post-exposure. However, 3 $\mathrm{ABC}$ ELISA and VIAA assays were proven to be effective tools for diagnosis and serological surveys of FMD exposure. Testing of oral swabs by rRT-PCR as a surveillance tool may be effective with the limitation that the window of detection is limited to the first two weeks of infection and within these two weeks infected animals may show sporadic positive results. Depending on the design and purpose of surveillance, serological testing combined with antigenic detection should provide the best temporal coverage.

This study shows that feral swine can easily acquire and transmit FMDV to other feral and to domestic swine and thereby pose a significant threat to the agricultural industry. Increased vigilance is required when conducting FMD surveillance in feral swine as they exhibit delays in presenting clinical signs, and lesions are often difficult to recognize. It is important to note however this study used only one FMDV isolate and other FMDV isolates may or may not exhibit similar virulence in feral swine. FMD control measures are more difficult to implement in feral 
swine populations, so it is important to set up surveillance programmes that emphasize early detection to try to minimize spread of the disease.

\section{Acknowledgements}

We thank Kathleen Apicelli and Ethan Macnow for photography, Dr. Luis Rodriguez (ARS) for providing the virus, the air sampling device and for reviewing the manuscript, Dr. Jonathan Arzt (ARS) for help with photomicroscopy, Dr. Ping Wu (APHIS) for help with the animal experiment, Dr. David Pyburn (APHIS) for purchasing the feral swine used in this study, Kerri Pedersen, Janean Romines, Mark Lutman, Michael Marlow, David Marks (Wildlife Services) for help with the animal experiment and special thanks to the Animal Resource Unit (DHS) of PIADC for help with animal care: Jeff Babcock, Anthony Gonzalez, John Brown, Philip Doucett, Donald Hermance, Amber Sabrosky, and Ralph Soto.

\section{References}

Alexandersen, S., M.B. Oleksiewicz, and A.I. Donaldson, 2001: The early pathogenesis of foot-and-mouth disease in pigs infected by contact: a quantitative time-course study using TaqMan RT-PCR. J. Gen. Virol. 82, 747-755.

Alexandersen, S., Z. Zhang, A.I. Donaldson, and A.J. Garland, 2003: The pathogenesis and diagnosis of foot-and-mouth disease. J. Comp. Pathol. 129, 1-36.

Brocchi, E., I.E. Bergmann, A. Dekker, D.J. Paton, D.J. Sammin, M. Greiner, S. Grazioli, F. De Simone, H. Yadin, B. Haas, N. Bulut, V. Malirat, E. Neitzert, N. Goris, S. Parida, K. Sorensen, and K. De Clercq, 2006: Comparative evaluation of six ELISAs for the detection of antibodies to the non-structural proteins of foot-and-mouth disease virus. Vaccine 24, 6966-6979.

Carrillo, C., Z. Lu, M.V. Borca, A. Vagnozzi, G.F. Kutish, and D.L. Rock, 2007: Genetic and phenotypic variation of footand-mouth disease virus during serial passages in a natural host. J. Virol. 81, 11341-11351.

Cowled, B., and G. Garner, 2008: A review of geospatial and ecological factors affecting disease spread in wild pigs: considerations for models of foot-and-mouth disease spread. Prev. Vet. Med. 87, 197-212.

Dexter, 2003: Scholastic models of foot and mouth disease in feral pigs in the Australian semi-arid rangelands. J. Appl. Ecol. 40, 293-306.

Doran, R.J., and S.W. Laffan, 2005: Simulating the spatial dynamics of foot and mouth disease outbreaks in feral pigs and livestock in Queensland, Australia, using a susceptibleinfected-recovered cellular automata model. Prev. Vet. Med. 70, 133-152.

Grubman, M.J., and B. Baxt, 2004: Foot-and-mouth disease. Clin. Microbiol. Rev. 17, 465-493.
Hoffmann, B., M. Beer, S.M. Reid, P. Mertens, C.A. Oura, P.A. van Rijn, M.J. Slomka, J. Banks, I.H. Brown, D.J. Alexander, and D.P. King, 2009: A review of RT-PCR technologies used in veterinary virology and disease control: sensitive and specific diagnosis of five livestock diseases notifiable to the World Organisation for Animal Health. Vet. Microbiol. 139, 1-23.

Hone, J., 1990: Disease surveillance in wildlife with emphasis on detecting foot and mouth disease in feral pigs. J. Environ. Manage. 31, 173-184.

Juleff, N., M. Windsor, E. Reid, J. Seago, Z. Zhang, P. Monaghan, I.W. Morrison, and B. Charleston, 2008: Foot-andmouth disease virus persists in the light zone of germinal centres. PLoS ONE 3, e3434.

Kitching, R.P., 2002: Identification of foot and mouth disease virus carrier and subclinically infected animals and differentiation from vaccinated animals. Rev. Sci. Tech. 21, 531-538.

Kitching, R.P., and G.J. Hughes, 2002: Clinical variation in foot and mouth disease: sheep and goats. Rev. Sci. Tech. 21, 505-512.

Mayer, J.J., and I.L., Brisbin Jr, 1991: Wild Pigs in the United States: Their History, Comparative Morphology, and Current Status. University of Georgia Press, Athen, Georgia.

McVicar, J.W., and P. Sutmoller, 1970: Foot-and-mouth disease: the agar gel diffusion precipitin test for antibody to virus-infection-associated (via) antigen as a tool for epizootiologic surveys. Am. J. Epidemiol. 92, 273-278.

Mezencio, J.M., G.D. Babcock, E. Kramer, and F. Brown, 1999: Evidence for the persistence of foot-and-mouth disease virus in pigs. Vet. J. 157, 213-217.

Moniwa, M., A. Clavijo, M. Li, B. Collignon, and P.R. Kitching, 2007: Performance of a foot-and-mouth disease virus reverse transcription-polymerase chain reaction with amplification controls between three real-time instruments. J. Vet. Diagn. Invest. 19, 9-20.

Morgan, D.O., D.M. Moore, and P.D. McKercher, 1978: Purification of foot-and-mouth disease virus infection-associated antigen. Proc. Annu. Meet. U S Anim. Health Assoc. 82, 277283.

Newman, J.F., B. Cartwright, T.R. Doel, and F. Brown, 1979: Purification and identification of the RNA-dependent RNA polymerase of foot-and-mouth disease virus. J. Gen. Virol. 45, 497-507.

Orsel, K., H.I. Roest, E.M. Elzinga-Bril, F. van HemertKluitenberg, and A. Dekker, 2008: Detection of foot-andmouth disease virus in infected pigs by RT-PCR four weeks after challenge. Vet. Rec. 162, 753-754.

Pacheco, J.M., and P.W. Mason, 2010: Evaluation of infectivity and transmission of different Asian foot-and-mouth disease viruses in swine. J. Vet. Sci. 11, 133-142.

Pech, R.P., and J. Hone, 1988: A model of the dynamics and control of an outbreak of foot and mouth disease in feral pigs in Australia. J. Appl. Ecol. 25, 63-77. 
Pech, R.P., and J.C. Mcllroy, 1990: A model of the velocity of advance of foot-and-mouth disease in feral pigs. J. Appl. Ecol. 27, 635-650.

Pimental, D., 2007: Environmental and economic costs of vertebrate species invasion into the United States. In: Witmer, G.W., W.C., Pitt, and E.K.A. Fagerstone (eds), Managing Vertebrate Invasive Species: Proceedings of an International Symposium pp. 2-8. USDA/APHIS/WS, National Wildlife Research Center, Fort Collins, CO.

Quan, M., C.M. Murphy, Z. Zhang, and S. Alexandersen, 2004: Determinants of early foot-and-mouth disease virus dynamics in pigs. J. Comp. Pathol. 131, 294-307.

Robertson, B.H., D.O. Morgan, D.M. Moore, M.J. Grubman, J. Card, T. Fischer, G. Weddell, D. Dowbenko, and D. Yansura, 1983: Identification of amino acid and nucleotide sequence of the foot-and-mouth disease virus RNA polymerase. Virology 126, 614-623.

Salt, J.S., G. Mulcahy, and R.P. Kitching, 1996: Isotype-specific antibody responses to foot-and-mouth disease virus in sera and secretions of "carrier' and "non-carrier' cattle. Epidemiol. Infect. 117, 349-360.

Sorensen, K.J., K.G. Madsen, E.S. Madsen, J.S. Salt, J. Nqindi, and D.K. Mackay, 1998: Differentiation of infection from vaccination in foot-and-mouth disease by the detection of antibodies to the non-structural proteins $3 \mathrm{D}, 3 \mathrm{AB}$ and $3 \mathrm{ABC}$ in ELISA using antigens expressed in baculovirus. Arch. Virol. 143, 1461-1476.

Ward, M.P., S.W. Laffan, and L.D. Highfield, 2007: The potential role of wild and feral animals as reservoirs of foot-andmouth disease. Prev. Vet. Med. 80, 9-23.

Wyckoff, A.C., S.E. Henke, T.A. Campbell, D.G. Hewitt, and K.C. VerCauteren, 2009: Feral swine contact with domestic swine: a serologic survey and assessment of potential for disease transmission. J. Wildl. Dis. 45, 422-429.

Zhang, Z., and J.B. Bashiruddin, 2009: Quantitative analysis of foot-and-mouth disease virus RNA duration in tissues of experimentally infected pigs. Vet. J. 180, 130-132. 